\title{
AN ENVIRONMENTAL JUSTICE ASSESSMENT OF THE MISSISSIPPI RIVER INDUSTRIAL CORRIDOR IN LOUISIANA, U.S. USING A GIS-BASED APPROACH
}

\author{
PERERA, P.K.P. ${ }^{1} *-$ LAM, N. ${ }^{2}$ \\ ${ }^{1}$ Institution Department of Forestry and Environmental Science, University of Sri \\ Jayewardenepura, Sri Lanka \\ (phone: +94-112758411; fax: +94-112803470) \\ ${ }^{2}$ Department of Environmental Sciences, School of the Coast and Environment, \\ Louisiana State University, Baton Rouge, LA, 70803, USA \\ (phone: +11-225-578-3030; fax: (225) 578-4286) \\ *Corresponding author \\ e-mail: priyan@sjp.ac.lk
}

(Received $12^{\text {th }}$ May 2013; accepted $5^{\text {th }}$ September 2013)

\begin{abstract}
Environmental justice has become an important topic in environmental sciences, and GIS is being increasingly used in environmental justice research to fully understand the relationship between low-income racial minorities and toxic facility locations. This study used GIS based proximity measures in combination with environmental justice indices to assess the status of environmental justice concerns in the Mississippi River Industrial Corridor in Louisiana. Comparative Environmental Risk Indices (CERI) for poverty and minority computed for parishes along the Mississippi River Industrial Corridor suggested a higher degree of environmental injustice in East Baton Rouge, Ascension, Jefferson, Orleans, St. Charles, St. James and St. John parishes. Standard Minority Ratios (SMIR) and Standard Poverty Ratios (SPR) provided stronger evidences for environmental injustice in the study area. The study approach allows preliminary assessment of environmental justice concerns, which has policy implications in industrial zone planning, and siting potentially toxic industrial facilities.
\end{abstract}

Keywords: Environmental injustice, Louisiana, GIS, Environmental justice indices

\section{Introduction}

The contemporary interest on Environmental Justice in the U.S. goes back to early 1980s where the U.S. General Accounting Office (GAO) was called upon to conduct a study on the location of hazardous waste landfills and the population's racial and economic status in North Carolina (GAO, 1983). The GAO report concluded that minority African American communities make up greater proportion of the population in areas where landfills are located. Following this study, the United Church of Christ's Commission for Racial Justice published a nationwide report in 1987, documenting the disproportionate exposure of communities of color to environmentally hazardous facilities. The report generated much discussion and debate among environmental and social activists, giving rise to the modern environmental justice movement in the U.S. The concept of environmental justice soon captured the attention of policy makers. As a result, the Clinton administration in 1994 passed an executive order, requesting federal agencies to take appropriate actions to address environmental justice concerns of minority and low-income populations in federal programs (Executive Order-12898, 1994). The Environmental Protection Agency (EPA) also formed the Office of Environmental Justice in 1992 to integrate environmental justice into EPA's policies, programs, and activities (EPA, 2009). At present, environmental justice has become an 
important topic in environmental circles and numerous studies have been conducted to understand the relationship between low-income racial minorities and toxic site locations.

Environmental justice communities typically comprise minority and low-income communities that are usually neglected in environmental policy decision making. As a result, these socially and economically disadvantaged groups are subjected to disproportionate impacts of environmental hazards, activities and policies. The U.S. EPA defines environmental justice as the "fair treatment for people of all races, cultures, and incomes, regarding the development of environmental laws, regulations, and policies" (EPA, 2009). The concept addresses social, economic as well as environmental concerns. At present, environmental justice is given a greater importance in land use planning (Kumar, 2002), transportation (Johnson and Kirk, 2004; Moynihan, 2007), housing, and public health projects (Maantay, 2002) where adverse discriminatory environmental consequences are possible.

Early environmental justice studies used various statistical tests and indices that were based on different geographic units of analysis (Capek, 1993; Bowen et al., 1995). Indices of environmental justice are used to explain the disproportionate exposure of minorities and people in poverty to environmental risks. For instance, Sheppard et al. (1999) used proximity ratios to perform a preliminary assessment of environmental equity in potential exposure to airborne toxic chemicals for racial minorities, people in poverty, and children in Minneapolis, U.S. Mertz and Slovic (2004) developed indices of environmental justice and social vulnerability to examine their effect on perceived risks. Harner et al. (2002) developed and tested seven environmental justice indices on three cities in Colorado, U.S. They proposed the Comparative Environmental Risk Index (CERI) as a preliminary, standardized measure for comparing urban areas.

Recently, Geographic Information Systems (GIS) has emerged as an important tool in identifying potential environmental injustice areas especially due to its ability to incorporate different types of data, perform spatial analytical techniques, and provide visually interpretable maps of complex data (Chakraborty and Armstrong, 1997; Sheppard et al., 1999; Mennis, 2002). A commonly used GIS based approach is the comparison of population demographics of enumeration units containing toxic sites with the rest of the population in study area. This may be performed via spatial coincidence or analytical buffering (Sheppard et al., 1999). In spatial coincidence method, proximate populations are defined as those residing in the census enumeration unit containing a TRI site. The GIS-based buffer analysis considers those who reside within a pre-defined distance from a TRI site as the proximate population. The application of distance buffers using GIS is considered a viable method of environmental justice evaluation. Chakraborty and Armstrong (1997) identify three such buffer analysis methods. (1.) The polygon containment method identifies the "atrisk" population by capturing all the enumeration units or census block groups that fully or partially overlap with the buffer. (2.) The buffer containment method assumes homogeneous distribution of population within an enumeration unit, and takes into account the percentage of enumeration unit that overlaps with the buffer in defining the at-risk population. (3.) In the centroid containment method, if the centroid of an enumeration unit falls within the buffer, the corresponding population is considered to be at-risk.

Numerous studies have used GIS based proximity techniques in environmental justice assessment (Sui and Giardino, 1995; McMaster et al., 1997; Larson and 
Claussen, 2004; Mohai and Saha, 2007). They assume individuals in a given area receive same level of exposure based on the presence or absence of polluting facilities. However, these proximity measures do not adequately account for the nature of toxic chemicals released, and their dispersion through various media. To eliminate this bias, certain studies have incorporated plume dispersion modes to assess the potential for exposure (Jerrett, 2001). Some authors expanded the use of GIS based techniques to examine environmental justice concerns due to non-point source pollution. For instance, by applying spatial point pattern analysis to account for the problem of differentiating non-point source pollution, Fisher et al. (2002) concluded West Oakland, CA in U.S. as a city where environmental injustice can be observed.

This study uses GIS based proximity measures in combination with environmental justice indices to assess environmental justice concerns in the Mississippi River Industrial Corridor in Louisiana, U.S. It investigates whether racial minority and lowincome groups are disproportionately exposed to the impacts of Toxics Release Inventory (TRI) sites/facilities along the Industrial Corridor.

\section{Materials and Methods}

\section{The study area}

The focus of this study was to conduct an environmental justice assessment of the Mississippi River Industrial Corridor in Louisiana (Figure 1). Stretching approximately 84 miles, Mississippi River Industrial Corridor between Baton Rouge and New Orleans has attracted numerous large-scale manufacturing companies over the years due to the availability of well-developed transportation networks, easy access to raw materials, and economies of agglomeration. According to EPA's Risk Screening Environmental Indicators (RSEI), parishes along the Mississippi River industrial corridor from Baton Rouge to the mouth of the Mississippi River are ranked at the top in terms of risk to human health for the state of Louisiana, U.S (Subra, 2008). The SERI also ranks East Baton Rouge Parish at the $24^{\text {th }}$ in the U.S. in terms of health risks. In the year 2005 alone, 57,921,138 kilograms of toxic wastes were released (on-site, off-site and other disposals) by TRI facilities in Louisiana (LEAN, 2009).

As a result of increased environmental regulations, monitoring and technological advances, the emissions by TRI facilities in the industrial corridor have decreased gradually over the years (LEAN, 2009). However, current emission levels still rank some of the industrial facilities located in the industrial corridor among top ranking chronic human health risk industrial facilities in the U.S. based on the EPA's RSEI (Subra, 2008).

Degradation of soil and plant life, water pollution, noxious hazes, reduced crop yields in river parishes and reduced numbers of fish in the waterways are some of the most common forms of environmental degradation observed in this area as a result of increased toxic emissions (Kurtz, 2003). In addition, earlier studies report elevated levels of cancer and respiratory diseases in communities exposed to toxic emissions (Gottlieb, 1980). 


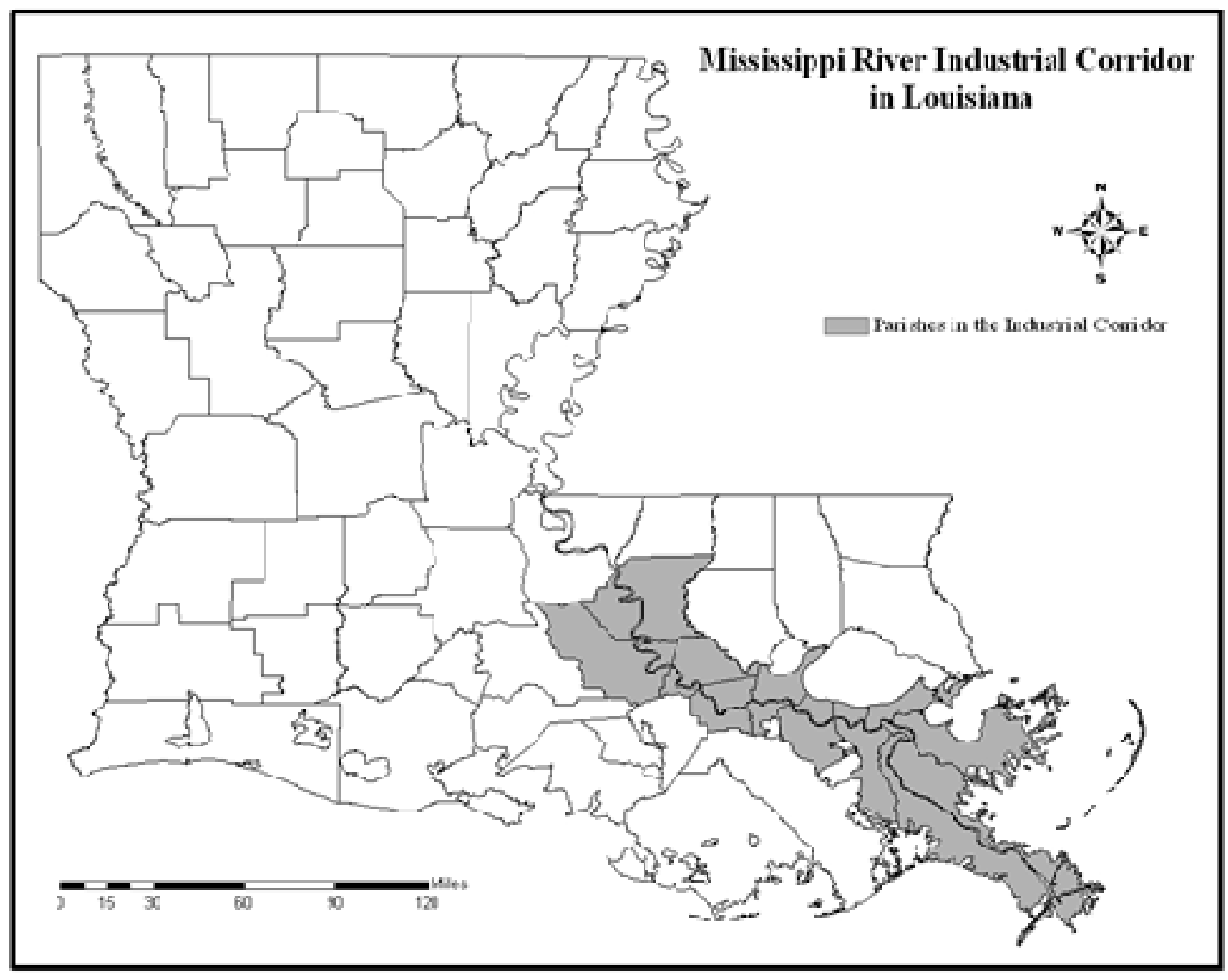

Figure 1. Mississippi River Industrial Corridor in Louisiana, U.S.

\section{Methods}

Environmental justice assessment in industrial areas using site locations deals with proximity. Spatial coincidence and analytical buffering involves examining the association between TRI sites with a pre-defined buffer, and the demographic characteristics retrieved within the buffer. TRI Industry locations were obtained from the EPA's Toxic Release Inventory database. The U.S. Census demographic data (race and household income) by census block group were downloaded from The Louisiana Statewide GIS website (Atlas, 2009). Minority is defined as Black, Asian American, American Indian, other race, and two or more races (U.S. Census Bureau, 2008). Average family size in Louisiana is 3.16 persons per family, and the poverty threshold for a family with three people is U.S. \$ 17,330 (U.S. Census Bureau, 2008). Therefore, households with annual income of US $\$ 20,000$ or less were considered to be in poverty for the purpose of this study. The data were imported into ArcMapTM environment to perform GIS analysis and create descriptive maps to illustrate the distribution of racial minorities and low income population. All analyses were performed using buffer distances of $0.5 \mathrm{~km}$ and $1 \mathrm{~km}$ from each TRI site.

Both descriptive and quantitative assessments were used in this study. Accordingly, two environmental justice indices described by Harner et al. (2002); Comparative Environmental Risk Index (CERI) and Toxic Demographic Difference Index (TDDI), were used. The CERI for minority (CERIm) and population in poverty (CERIp) indices were computed as follows. 


$$
\begin{aligned}
& \text { CERI }_{m}=\frac{(\text { At }- \text { risk minority population } / \text { Total minority population in the county })}{(\text { At }- \text { risk white population /Total white population in the county })} \\
& \text { CERI }_{p}=\frac{(\text { At }- \text { risk population in poverty /T otal poverty population in the county })}{(\text { At }- \text { risk population above poverty limit/Total county population above poverty limit })}
\end{aligned}
$$

Toxic Demographic Differences Index (TDDI) measures whether there's a statistically significant difference between minority and poor populations near TRI sites and those live away from TRI sites. A t- test is used to compare means of minority and poverty data inside the buffer areas to remaining county data. The $t$-value indicates the probability of inequality occurring at random, and (1-p) is the index for each variable (Harner et al., 2002).

This study further assesses whether minority and low-income populations are more concentrated around TRI sites, using indices called Standardized Minority Ratios (SMIR) and Standardized Poverty Ratios (SPR). SMIR was calculated by dividing the observed number of minority individuals by the expected number of minority individuals in the unit of analysis. Similarly, the observed number of households in poverty was divided by the expected number of households in poverty to obtain SPR. In computing SMIR, the expected number was derived by multiplying the minority rate corresponding to a unit of analysis by the population in the unit of analysis. The same process was repeated for the poverty data to compute the expected number. This procedure generates two indices/ratios (SMIR and SPR) indicating the degree of which minority and low-income populations are concentrated within a pre-defined buffer around TRI sites. If the observed and expected values are equal, the ratio will equal to one. Values below 1.0 indicate reduced or moderate concentrations, while values from 1 upwards indicate unusually higher concentrations of minority and low-income populations near TRI sites (Kahn and Sempos, 1989). A 95\% confidence interval (CI) of the SMIR and SPR was used to evaluate the statistical significance. It evaluates the probability that the SMIR or SPR may be less than or greater than 1.0 exclusively due to chance. A 95\% CI that includes 1.0 denotes that the SMIR or SPR is not significantly different from 1.0 statistically (Kahn and Sempos, 1989).

\section{Results}

The GIS-based proximity analysis of the industrial corridor focuses on the location of socio-economically disadvantaged groups and their distances from the TRI cites. This study uses two indicator demographic variables to identify vulnerable populations; (1) the predominance of economically stressed or poor population and (2) high percent of minority population in close proximity to TRI sites. The smallest unit of analysis is the census block group.

\section{Descriptive Analysis}

Identifying the distribution pattern of low-income and minority population close to TRI sites is a key step in environmental justice assessment. Demographic and household income data from U.S. Census Bureau in ArcMapTM environment was used for this purpose. Figure 2 illustrates the percent minority in the study area (parishes fall into the industrial corridor) per census block. It can be observed that many TRI sites are located 
in block groups with a high percentage of minorities. This is more evident particularly in East Baton Rouge, Iberville, St. Johns, St. James, and Ascension parishes where TRI sites tend to cluster around census blocks that represent over $50 \%$ minority population.

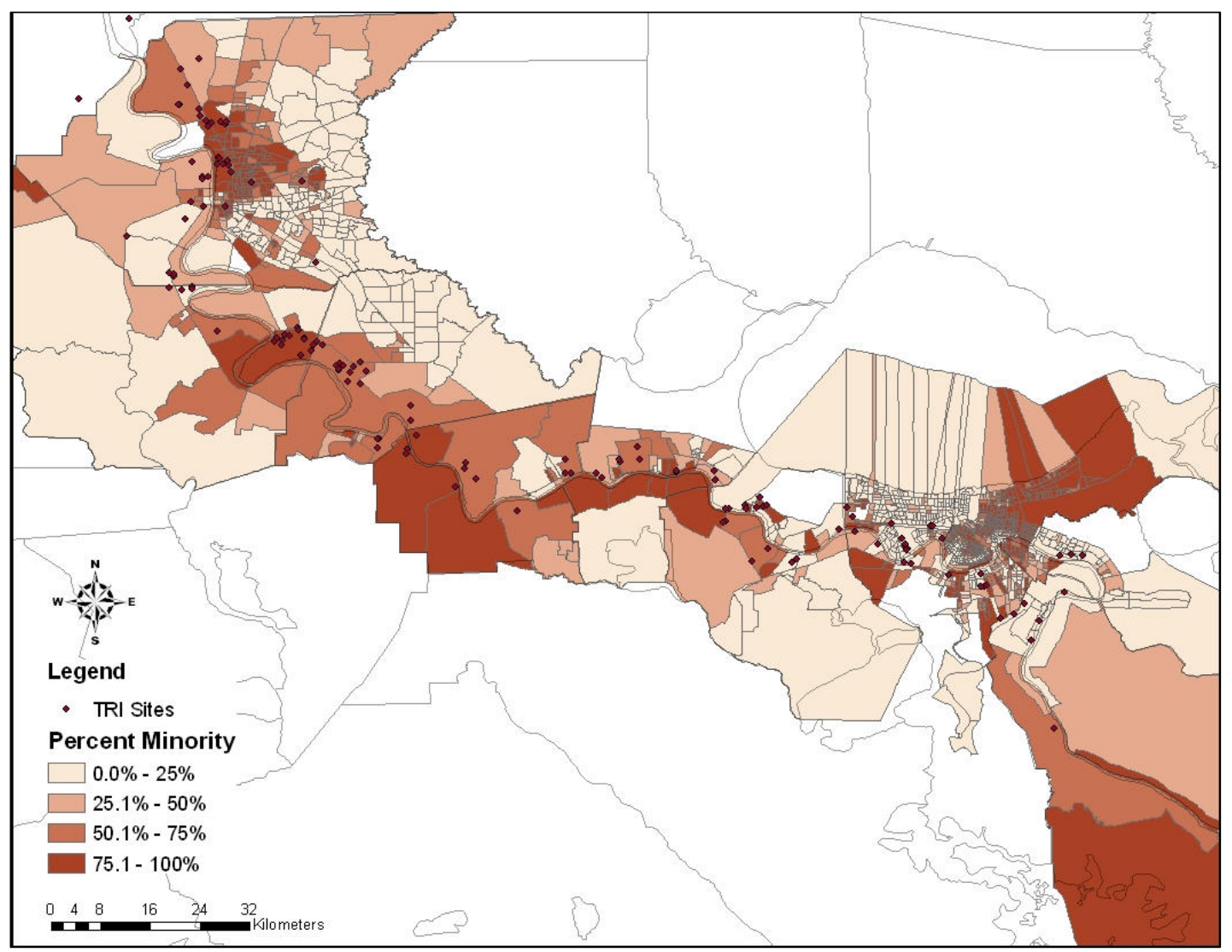

Figure 2. Percent Minority per Census Block in the Mississippi River Industrial Corridor

To identify whether the spatial pattern of low-income population is associated with TRI site locations, household income data was used. Figure 3 illustrate the percent households with income below \$20,000/year. Higher densities/clusters of TRI sites in block groups that represent 33.4 to $100 \%$ of population with income less than \$20000/year can be observed in East Baton Rouge, Iberville, St. Johns, and St. James parishes. 


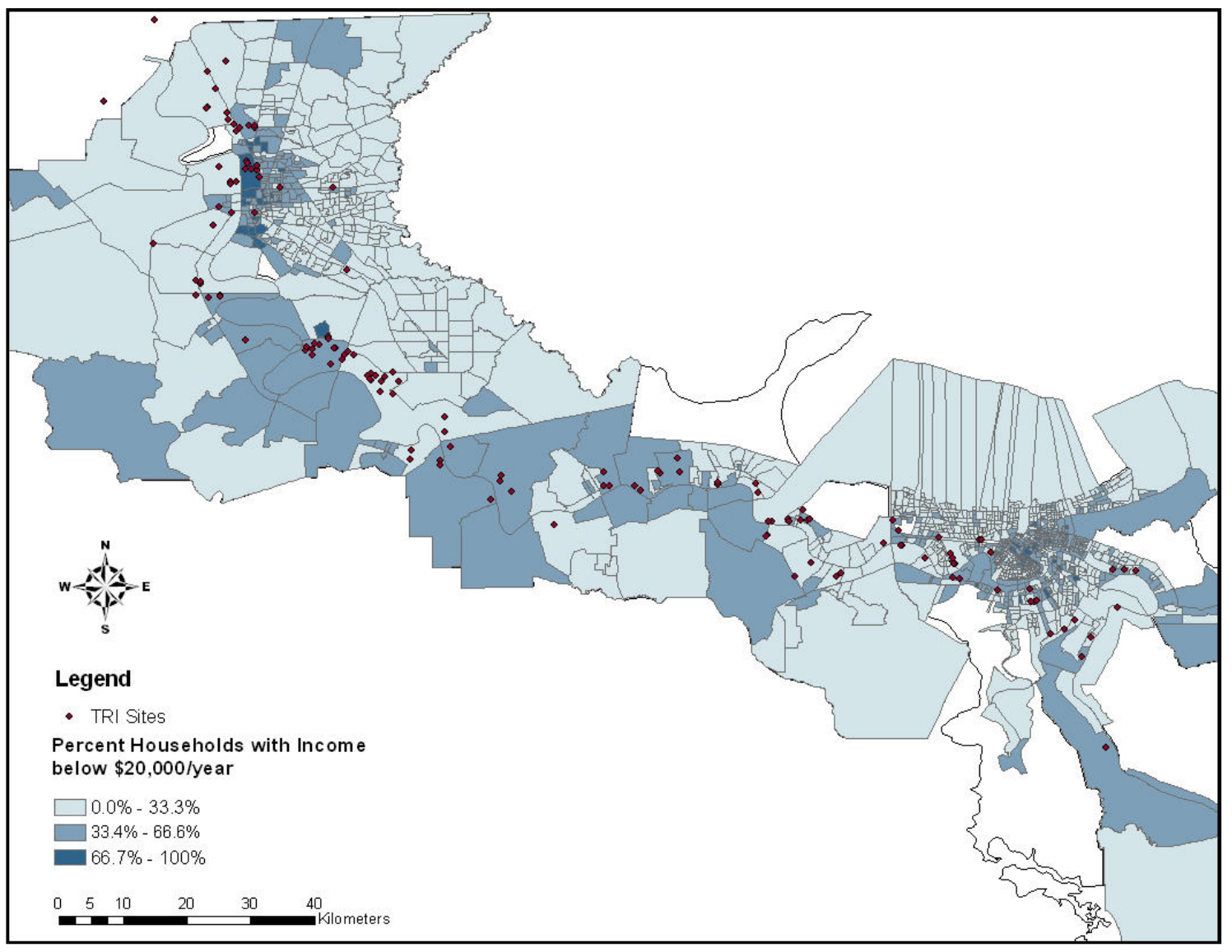

Figure 3. Percent Households with Annual Income below \$20,000 per Census Block Group in the Mississippi River Industrial Corridor

\section{Quantitative Assessments of Environmental Justice}

To assess environmental justice concerns quantitatively, Environmental Justice Indices and other statistical methods were used. CERI and TDDI Environmental Justice Indices were employed to assess the "disproportionate impact". Buffer distance is often selected based on the type and distribution of pollutant. Since the nature of pollutants at each TRI site is not taken into consideration here, buffer distances recommended by previous studies i.e. $0.5 \mathrm{~km}$ and $1 \mathrm{~km}$ distances from TRI sites were used (Sheppard et al., 1999; Harner et al., 2002). "At-risk" and "not at-risk" populations were determined based on the polygon containment method (Figure 4). 


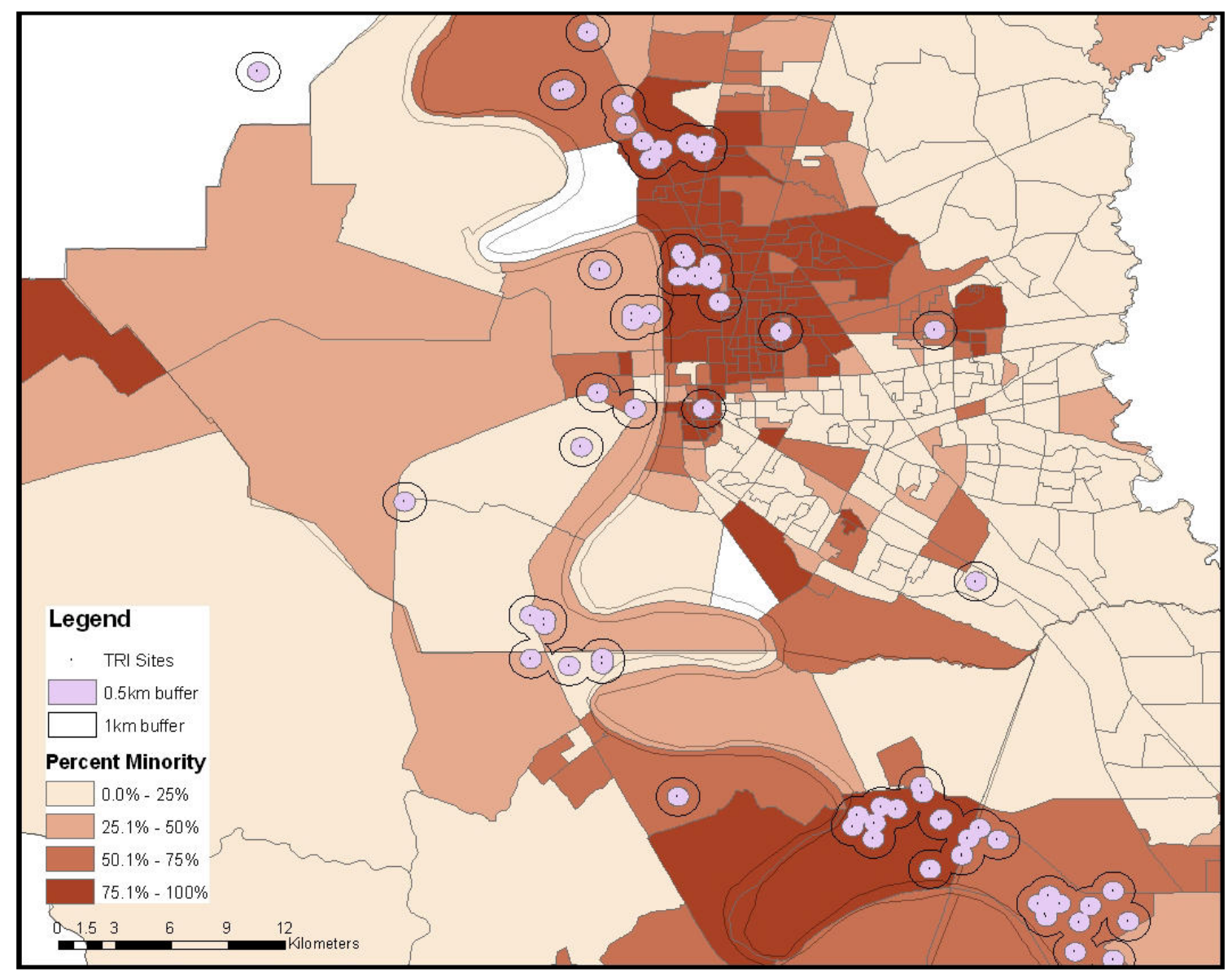

Figure 4. Block Groups Intersect with $0.5 \mathrm{~km}$ and $1 \mathrm{~km}$ Buffers around TRI Sites (Minority)

\section{Comparative Environmental Risk Index (CERI)}

This index measures whether minorities and low-income people are more likely to be exposed to environmental hazards than are the rest of the population. According to the results the minority as a group are at greater toxic risk in East Baton Rouge, Ascension, Iberville, Jefferson, Orleans, St. Charles, St. James and St. John parishes (Table 1). CERIm is much higher for East Baton Rouge, Ascension and Orleans parishes, especially at $0.5 \mathrm{~km}$ buffer from TRI sites, suggesting more serious environmental justice concerns. Increasing the buffer size from $0.5 \mathrm{~km}$ to $1 \mathrm{~km}$ either increased or decreased the CERIm, depending on the population captured by the buffer. 
Table 1. Comparative Environmental Risk Indices for Minority

\begin{tabular}{c|c|c|c|c}
\hline Parish & Buffer & $\begin{array}{c}\text { At risk minority } \\
\text { Parish minority }\end{array}$ & $\frac{\text { At risk whites }}{\text { Parish whites }}$ & CERI $_{\mathbf{~}}$ \\
\hline East Baton Rouge & $0.5 \mathrm{~km}$ & 0.126 & 0.027 & 4.667 \\
& $1 \mathrm{~km}$ & 0.268 & 0.097 & 2.770 \\
Ascension & $0.5 \mathrm{~km}$ & 0.205 & 0.066 & 3.125 \\
& $1 \mathrm{~km}$ & 0.315 & 0.080 & 3.912 \\
Iberville & $0.5 \mathrm{~km}$ & 0.399 & 0.310 & 1.286 \\
& $1 \mathrm{~km}$ & 0.506 & 0.363 & 1.395 \\
Jefferson & $0.5 \mathrm{~km}$ & 0.146 & 0.120 & 1.212 \\
& $1 \mathrm{~km}$ & 0.234 & 0.228 & 1.024 \\
Orleans & $0.5 \mathrm{~km}$ & 0.006 & 0.001 & 4.458 \\
& $1 \mathrm{~km}$ & 0.023 & 0.020 & 1.145 \\
Plaquemines & $0.5 \mathrm{~km}$ & 0.265 & 0.455 & 0.581 \\
& $1 \mathrm{~km}$ & 0.313 & 0.625 & 0.501 \\
St. Bernard & $0.5 \mathrm{~km}$ & 0.079 & 0.119 & 0.661 \\
& $1 \mathrm{~km}$ & 0.121 & 0.297 & 0.405 \\
St. Charles & $0.5 \mathrm{~km}$ & 0.388 & 0.318 & 1.222 \\
& $1 \mathrm{~km}$ & 0.388 & 0.318 & 1.222 \\
St. James & $0.5 \mathrm{~km}$ & 0.453 & 0.289 & 1.567 \\
& $1 \mathrm{~km}$ & 0.552 & 0.462 & 1.195 \\
St. John & $0.5 \mathrm{~km}$ & 0.258 & 0.203 & 1.269 \\
& $1 \mathrm{~km}$ & 0.374 & 0.298 & 1.255 \\
West Baton Rouge & $0.5 \mathrm{~km}$ & 0.506 & 0.674 & 0.750 \\
& $1 \mathrm{~km}$ & 0.633 & 0.706 & 0.896 \\
\hline
\end{tabular}

Table 2 summarizes the CERI computations for populations in poverty. This index also suggests that households with income less than \$20000/year are more concentrated around TRI sites in East Baton Rouge, Ascension, Jefferson, Orleans, St. Bernard, St. Charles, St. James and St. John parishes. Highest CERIp was observed in East Baton Rouge parish followed by St. Charles and Orleans parishes. The concentration of households in poverty is higher at both $0.5 \mathrm{~km}$ and $1 \mathrm{~km}$ buffer distances for these parishes. When considered the CERI for poverty and minority, higher possibilities of environmental justice issues exist in East Baton Rouge, Ascension, Jefferson, Orleans, St. Charles, St. James and St. John parishes in the Mississippi industrial corridor. In general, CERI for minority are much higher than that of the poverty, suggesting that race is subject to more environmental injustice than poverty. 
Table 2. Comparative Environmental Risk Indices for Populations in Poverty

\begin{tabular}{c|c|c|c|c}
\hline Parish & Buffer & $\frac{\text { At risk poor }}{\text { Parish poor }}$ & $\frac{\text { At risk non-poor }}{\text { Parish non-poor }}$ & CERI $_{\mathbf{p}}$ \\
\hline East Baton Rouge & $0.5 \mathrm{~km}$ & 0.082 & 0.055 & 1.491 \\
& $1 \mathrm{~km}$ & 0.204 & 0.078 & 2.610 \\
Ascension & $0.5 \mathrm{~km}$ & 0.094 & 0.092 & 1.026 \\
& $1 \mathrm{~km}$ & 0.157 & 0.118 & 1.331 \\
Iberville & $0.5 \mathrm{~km}$ & 0.261 & 0.305 & 0.858 \\
& $1 \mathrm{~km}$ & 0.366 & 0.378 & 0.968 \\
Jefferson & $0.5 \mathrm{~km}$ & 0.138 & 0.127 & 1.082 \\
& $1 \mathrm{~km}$ & 0.234 & 0.228 & 1.026 \\
Orleans & $0.5 \mathrm{~km}$ & 0.005 & 0.004 & 1.436 \\
& $1 \mathrm{~km}$ & 0.024 & 0.019 & 1.250 \\
Plaquemines & $0.5 \mathrm{~km}$ & 0.324 & 0.428 & 0.758 \\
& $1 \mathrm{~km}$ & 0.471 & 0.588 & 0.801 \\
St. Bernard & $0.5 \mathrm{~km}$ & 0.164 & 0.112 & 1.466 \\
& $1 \mathrm{~km}$ & 0.300 & 0.283 & 1.058 \\
St. Charles & $0.5 \mathrm{~km}$ & 0.469 & 0.322 & 1.455 \\
& $1 \mathrm{~km}$ & 0.469 & 0.322 & 1.455 \\
St. James & $0.5 \mathrm{~km}$ & 0.398 & 0.357 & 1.112 \\
& $1 \mathrm{~km}$ & 0.501 & 0.500 & 1.003 \\
St. John & $0.5 \mathrm{~km}$ & 0.326 & 0.199 & 1.638 \\
& $1 \mathrm{~km}$ & 0.435 & 0.299 & 1.453 \\
West Baton Rouge & $0.5 \mathrm{~km}$ & 0.565 & 0.612 & 0.924 \\
& $1 \mathrm{~km}$ & 0.671 & 0.673 & 0.998 \\
\hline
\end{tabular}

\section{Toxic Demographic Difference Index (TDDI)}

The TDDIm and TDDIp indices were computed for 0.5- and 1-km buffer distances respectively. The minority proportions of the population in "at-risk" areas are higher than their proportions in "not-at-risk" areas for Ascension and East Baton Rouge parishes at both $0.5-\mathrm{km}$ and $1-\mathrm{km}$ buffer distances, and this inequality is statistically significant (Table 3). Interestingly, the not-at risk minority population means are higher than at-risk minority population means in Orleans, Plaquemines, St. Bernard, St. Charles, St. John, and West Baton Rouge parishes although the differences are statistically not significant at 0.05 significance level, except for Orleans parish at 0.5 $\mathrm{km}$ and St. Bernard at 1-km buffer distance. 
Table 3. Toxic Demographic Differences Indices for Minority (TDDIm)

\begin{tabular}{c|c|c|c|c|c|c}
\hline Parish & Buffer & $\begin{array}{c}\text { At Risk } \\
\text { Mean }\end{array}$ & $\begin{array}{c}\text { Not at Risk } \\
\text { Mean }\end{array}$ & $\begin{array}{c}\text { T value } \\
\text { (one tail) }\end{array}$ & $\begin{array}{c}\text { Probability } \\
\text { (p) }\end{array}$ & TDDIm \\
\hline Ascension & $0.5 \mathrm{~km}$ & 875.75 & 339.65 & 3.1819 & $0.0167 *$ & 0.9833 \\
East Baton Rouge & $1 \mathrm{~km}$ & 1076.20 & 300.21 & 3.2325 & $0.0160^{*}$ & 0.9840 \\
Iberville & $0.5 \mathrm{~km}$ & 784.62 & 568.42 & 2.6345 & $0.0060^{*}$ & 0.9940 \\
& $1 \mathrm{~km}$ & 755.36 & 545.52 & 3.1592 & $0.0120^{*}$ & 0.9880 \\
Jefferson & $0.5 \mathrm{~km}$ & 1116.83 & 674.20 & 1.2716 & 0.1221 & 0.8779 \\
& $1 \mathrm{~km}$ & 1064.25 & 638.46 & 1.4559 & 0.0837 & 0.9163 \\
Orleans & $0.5 \mathrm{~km}$ & 399.86 & 382.29 & 0.2229 & 0.4122 & 0.5878 \\
& $1 \mathrm{~km}$ & 345.08 & 397.29 & -0.8980 & 0.1852 & 0.8148 \\
Plaquemines & $0.5 \mathrm{~km}$ & 524.25 & 719.80 & -4.4211 & $0.0002 *$ & 0.9998 \\
St. Bernard & $1 \mathrm{~km}$ & 607.38 & 721.24 & -0.6802 & 0.2542 & 0.7458 \\
& $0.5 \mathrm{~km}$ & 213.10 & 348.18 & -1.1394 & 0.1327 & 0.8673 \\
St. Charles & $1 \mathrm{~km}$ & 180.07 & 425.31 & -1.9430 & $0.0339 *$ & 0.9661 \\
St. James & $0.5 \mathrm{~km}$ & 102.67 & 167.26 & -1.2023 & 0.1205 & 0.8795 \\
& $1 \mathrm{~km}$ & 67.21 & 196.20 & -2.4485 & $0.0094 *$ & 0.9906 \\
St. John & $0.5 \mathrm{~km}$ & 323.00 & 452.11 & -0.9754 & 0.1688 & 0.8312 \\
& $1 \mathrm{~km}$ & 323.00 & 452.11 & -0.9754 & 0.1688 & 0.8312 \\
West Baton Rouge & $0.5 \mathrm{~km}$ & 688.00 & 484.50 & 1.0387 & 0.1589 & 0.8411 \\
& $1 \mathrm{~km}$ & 586.50 & 529.44 & 0.2918 & 0.3871 & 0.6129 \\
& $0.5 \mathrm{~km}$ & 659.88 & 660.96 & -0.0054 & 0.4979 & 0.5021 \\
& $1 \mathrm{~km}$ & 589.38 & 712.17 & -0.5350 & 0.2990 & 0.7010 \\
& $0.5 \mathrm{~km}$ & 508.88 & 795.80 & -1.4850 & 0.0906 & 0.9094 \\
& $1 \mathrm{~km}$ & 565.89 & 739.25 & -0.7636 & 0.2398 & 0.7602 \\
\hline
\end{tabular}

*Statistically significant at the $p<0.05$ level

Table 4 indicates that mean of the households with annual income below $\$ 20,000$ "at-risk" population are higher than that of the "not-at risk" population in Ascension, St. Bernard, and St. John parishes. However, the only statistically significant environmental justice concern was observed in St. John parish at 0.5-km buffer distance, where low income populations are at greater environmental risk. 
Table 4. Toxic Demographic Differences Indices for Poverty (TDDIp)

\begin{tabular}{c|c|c|c|c|c|c}
\hline Parish & Buffer & $\begin{array}{c}\text { At Risk } \\
\text { Mean }\end{array}$ & $\begin{array}{c}\text { Not at Risk } \\
\text { Mean }\end{array}$ & $\begin{array}{c}\text { T value } \\
\text { (one tail) }\end{array}$ & $\begin{array}{c}\text { Probability } \\
\text { (p) }\end{array}$ & TDDI $_{\mathbf{p}}$ \\
\hline Ascension & $0.5 \mathrm{~km}$ & 135.50 & 130.53 & 0.1796 & 0.4331 & 0.5669 \\
& $1 \mathrm{~km}$ & 181.40 & 124.51 & 1.1179 & 0.1631 & 0.8369 \\
East Baton Rouge & $0.5 \mathrm{~km}$ & 122.79 & 143.31 & -1.2136 & 0.1158 & 0.8842 \\
Iberville & $1 \mathrm{~km}$ & 138.33 & 142.59 & -0.2918 & 0.3855 & 0.6145 \\
& $0.5 \mathrm{~km}$ & 169.67 & 191.67 & -0.3946 & 0.3512 & 0.6488 \\
Jefferson & $1 \mathrm{~km}$ & 178.00 & 189.92 & -0.2457 & 0.4044 & 0.5956 \\
& $0.5 \mathrm{~km}$ & 116.64 & 119.10 & -0.1781 & 0.4296 & 0.5704 \\
Orleans & $1 \mathrm{~km}$ & 106.69 & 123.69 & -1.5089 & 0.0664 & 0.9336 \\
& $0.5 \mathrm{~km}$ & 95.25 & 151.58 & -2.2208 & 0.0565 & 0.9435 \\
Plaquemines & $1 \mathrm{~km}$ & 134.85 & 152.05 & -0.8048 & 0.2172 & 0.7828 \\
St. Bernard & $0.5 \mathrm{~km}$ & 79.00 & 96.94 & -0.7317 & 0.2359 & 0.7641 \\
& $1 \mathrm{~km}$ & 82.00 & 99.23 & -0.6746 & 0.2531 & 0.7469 \\
St. Charles & $0.5 \mathrm{~km}$ & 180.50 & 128.16 & 1.4841 & 0.0907 & 0.9093 \\
St. James & $1 \mathrm{~km}$ & 141.21 & 136.94 & 0.1610 & 0.4365 & 0.5635 \\
& $0.5 \mathrm{~km}$ & 95.69 & 96.39 & -0.0394 & 0.4844 & 0.5156 \\
St. John & $1 \mathrm{~km}$ & 95.69 & 96.39 & -0.0394 & 0.4844 & 0.5156 \\
& $0.5 \mathrm{~km}$ & 122.29 & 108.08 & 0.6171 & 0.2732 & 0.7268 \\
West Baton Rouge & $1 \mathrm{~km}$ & 107.90 & 119.33 & -0.4677 & 0.3236 & 0.6764 \\
& $0.5 \mathrm{~km}$ & 147.38 & 105.87 & 1.8229 & $0.0442 *$ & 0.9558 \\
& $1 \mathrm{~km}$ & 120.92 & 113.44 & 0.3288 & 0.3724 & 0.6276 \\
& $0.5 \mathrm{~km}$ & 142.88 & 163.83 & -0.6290 & 0.2711 & 0.7289 \\
& $1 \mathrm{~km}$ & 150.78 & 166.25 & -0.4067 & 0.3492 & 0.6508 \\
\hline
\end{tabular}

*Statistically significant at the $p<0.05$ level

\section{Standardized Minority Ratios (SMIR) and Standardized Poverty Ratios (SPR)}

Summary results of SMIR analysis for each parish are given in Table 5. Highest SMIRs were observed in Ascension parish followed by East Baton Rouge, Orleans and St. James parishes. SMIRs are significantly higher at 95\% confidence level for all the parishes, indicating higher concentrations of minority populations near TRI sites, except Plaquemines, St. Bernard and West Baton Rouge parishes, The results did not differ at both $0.5-\mathrm{km}$ and $1-\mathrm{km}$ buffer distance analysis. 
Table 5. Standardized Minority Ratios (SMIR) of Expected and Observed Minority Populations

\begin{tabular}{|c|c|c|c|c|c|c|}
\hline \multirow{2}{*}{ Parish } & \multirow{2}{*}{ Buffer } & \multirow{2}{*}{$\begin{array}{l}\text { Observed } \\
\text { Minority }\end{array}$} & \multirow{2}{*}{$\begin{array}{l}\text { Expected } \\
\text { Minority }\end{array}$} & \multirow{2}{*}{ SMIR } & \multicolumn{2}{|c|}{$95 \% \mathrm{CI}$} \\
\hline & & & & & Lower & Upper \\
\hline \multirow[t]{2}{*}{ Ascension } & $0.5 \mathrm{~km}$ & 3503 & 1652.10 & $2.12 *$ & 2.05 & 2.19 \\
\hline & $1 \mathrm{~km}$ & 5381 & 2268.74 & $2.37^{*}$ & 2.31 & 2.44 \\
\hline \multirow[t]{2}{*}{ East Baton Rouge } & $0.5 \mathrm{~km}$ & 22754 & 12693.58 & $1.79 *$ & 1.77 & 1.82 \\
\hline & $1 \mathrm{~km}$ & 48343 & 30946.31 & $1.56^{*}$ & 1.55 & 1.58 \\
\hline \multirow[t]{2}{*}{ Iberville } & $0.5 \mathrm{~km}$ & 6701 & 5961.10 & $1.12 *$ & 1.10 & 1.15 \\
\hline & $1 \mathrm{~km}$ & 8514 & 7319.54 & $1.16^{*}$ & 1.14 & 1.19 \\
\hline \multirow[t]{2}{*}{ Jefferson } & $0.5 \mathrm{~km}$ & 19993 & 17545.31 & $1.14^{*}$ & 1.12 & 1.16 \\
\hline & $1 \mathrm{~km}$ & 32092 & 31570.64 & $1.02 *$ & 1.01 & 1.03 \\
\hline \multirow[t]{2}{*}{ Orleans } & $0.5 \mathrm{~km}$ & 2097 & 1639.29 & $1.28 *$ & 1.23 & 1.34 \\
\hline & $1 \mathrm{~km}$ & 7896 & 7612.88 & $1.04 *$ & 1.01 & 1.06 \\
\hline \multirow[t]{2}{*}{ Plaquemines } & $0.5 \mathrm{~km}$ & 2131 & 3204.42 & 0.67 & 0.64 & 0.69 \\
\hline & $1 \mathrm{~km}$ & 2521 & 4277.87 & 0.59 & 0.57 & 0.61 \\
\hline \multirow[t]{2}{*}{ St. Bernard } & $0.5 \mathrm{~km}$ & 616 & 895.09 & 0.69 & 0.63 & 0.74 \\
\hline & $1 \mathrm{~km}$ & 941 & 2161.72 & 0.44 & 0.41 & 0.46 \\
\hline \multirow[t]{2}{*}{ St. Charles } & $0.5 \mathrm{~km}$ & 5168 & 4490.14 & $1.15^{*}$ & 1.12 & 1.18 \\
\hline & $1 \mathrm{~km}$ & 5168 & 4490.14 & $1.15^{*}$ & 1.12 & 1.18 \\
\hline \multirow[t]{2}{*}{ St. James } & $0.5 \mathrm{~km}$ & 4816 & 3947.67 & $1.22 *$ & 1.19 & 1.25 \\
\hline & $1 \mathrm{~km}$ & 5865 & 5387.15 & $1.09 *$ & 1.06 & 1.12 \\
\hline \multirow{2}{*}{ St. John } & $0.5 \mathrm{~km}$ & 5279 & 4692.97 & $1.12 *$ & 1.09 & 1.16 \\
\hline & $1 \mathrm{~km}$ & 7662 & 6846.98 & $1.12 *$ & 1.09 & 1.14 \\
\hline \multirow[t]{2}{*}{ West Baton Rouge } & $0.5 \mathrm{~km}$ & 4071 & 4921.83 & 0.83 & 0.80 & 0.85 \\
\hline & $1 \mathrm{~km}$ & 5093 & 5464.43 & 0.93 & 0.91 & 0.96 \\
\hline
\end{tabular}

*Statistically elevated at the $p<0.05$ level

Table 6 presents SPRs, which compares expected and observed low-income populations within $0.5-\mathrm{km}$ and $1-\mathrm{km}$ buffer distances from TRI sites. For East Baton Rouge, Orleans, St. Charles and St. John parishes, SPRs were significantly higher at the 95\% confidence level for both distance buffers. This indicates possible environmental justice concerns since low income populations tend to show higher concentrations around TRI sites. SPRs were significant only at the $0.5 \mathrm{~km}$ buffer distance analysis in Jefferson and St. Bernard parishes. 
Table 6. Standardized Poverty Ratios (SPR) and Expected and Observed Low-income Population Comparisons

\begin{tabular}{c|c|c|c|c|c|c}
\hline \multirow{2}{*}{ Parish } & \multirow{2}{*}{ Buffer } & $\begin{array}{c}\text { Observed } \\
\text { Poverty }\end{array}$ & $\begin{array}{c}\text { Expected } \\
\text { Poverty }\end{array}$ & \multirow{2}{*}{ SPR } & \multicolumn{2}{|c}{ 95\% CI } \\
\cline { 5 - 7 } Ascension & $0.5 \mathrm{~km}$ & 542 & 531.03 & 1.02 & 0.94 & 1.11 \\
& $1 \mathrm{~km}$ & 907 & 729.93 & $1.24^{*}$ & 1.16 & 1.33 \\
East Baton Rouge & $0.5 \mathrm{~km}$ & 3561 & 2713.38 & $1.31^{*}$ & 1.27 & 1.36 \\
& $1 \mathrm{~km}$ & 8853 & 7037.07 & $1.26^{*}$ & 1.23 & 1.28 \\
Iberville & $0.5 \mathrm{~km}$ & 1018 & 1125.00 & 0.90 & 0.85 & 0.96 \\
& $1 \mathrm{~km}$ & 1424 & 1454.04 & 0.98 & 0.93 & 1.03 \\
Jefferson & $0.5 \mathrm{~km}$ & 5832 & 5496.20 & $1.06^{*}$ & 1.03 & 1.09 \\
& $1 \mathrm{~km}$ & 9922 & 9729.80 & 1.02 & 1.00 & 1.04 \\
Orleans & $0.5 \mathrm{~km}$ & 381 & 310.27 & $1.23^{*}$ & 1.11 & 1.36 \\
& $1 \mathrm{~km}$ & 1753 & 1538.50 & $1.14^{*}$ & 1.09 & 1.19 \\
Plaquemines & $0.5 \mathrm{~km}$ & 790 & 974.28 & 0.81 & 0.76 & 0.87 \\
& $1 \mathrm{~km}$ & 1148 & 1356.46 & 0.85 & 0.80 & 0.90 \\
St. Bernard & $0.5 \mathrm{~km}$ & 1083 & 829.48 & $1.31^{*}$ & 1.23 & 1.39 \\
& $1 \mathrm{~km}$ & 1977 & 1897.57 & 1.04 & 1.00 & 1.09 \\
St. Charles & $0.5 \mathrm{~km}$ & 1531 & 1147.77 & $1.33^{*}$ & 1.27 & 1.40 \\
& $1 \mathrm{~km}$ & 1531 & 1147.77 & $1.33^{*}$ & 1.27 & 1.40 \\
St. James & $0.5 \mathrm{~km}$ & 856 & 796.11 & 1.08 & 1.00 & 1.15 \\
& $1 \mathrm{~km}$ & 1079 & 1076.65 & 1.00 & 0.94 & 1.06 \\
St. John & $0.5 \mathrm{~km}$ & 1179 & 836.17 & $1.41^{*}$ & 1.33 & 1.49 \\
& $1 \mathrm{~km}$ & 1572 & 1206.19 & $1.30^{*}$ & 1.24 & 1.37 \\
West Baton Rouge & $0.5 \mathrm{~km}$ & 1143 & 1212.62 & 0.94 & 0.89 & 1.00 \\
& $1 \mathrm{~km}$ & 1357 & 1359.42 & 1.00 & 0.95 & 1.05 \\
\hline
\end{tabular}

*Statistically elevated at the $p<0.05$ level

\section{Conclusion}

Industrial expansion in the Mississippi River Industrial Corridor between Baton Rouge and New Orleans has raised questions about environmental equity for those who live in the river parishes. This study based on Mississippi River Industrial Corridor parishes analyzed whether the minority and low income populations are disproportionally impacted by the locations of TRI facilities. GIS was used to produce visually interpretable environmental justice maps in addition to environmental justice indices in this work.

Mapping of percent minority (Figure 2) and percent households with annual income below $\$ 20,000$ (Figure 3) per census block group with the distribution of TRI locations show that most TRI facilities are located in block groups dominated by minorities and population in poverty. This is more evident particularly in East Baton Rouge, Iberville, St. Johns, St. James, and Ascension parishes.

Harner et al. recommend the adoption of CERI as a reliable standardized environmental justice indicator. This study reported higher CERI values for minority populations in East Baton Rouge, Ascension and Orleans parishes, especially at the 0.5$\mathrm{km}$ buffer from the TRI sites, suggesting higher degree of environmental justice concerns. Although this index does not adequately measure risk, it can be used as a preliminary indicator to compare different locations. The computed TDDI suggests minority populations are more concentrated in "at-risk" areas for Ascension and East Baton Rouge parishes. According to TDDI computed for low-income populations, St. John parish showed a significantly higher concentration of poor near TRI facilities. 
SMIR and SPR produced stronger evidences for the presence of environmental justice concerns in the study area. SMIRs were significantly higher at the $95 \%$ confidence level for all the parishes except Plaquemines, St. Bernard and West Baton Rouge parishes, indicating higher concentrations of minority populations near TRI sites in all other parishes. Statistically elevated SPRs at the 95\% confidence level for East Baton Rouge, Orleans, St. Charles, and St. John parishes suggest possible environmental justice concerns associated with low- income populations around TRI sites. Results further suggest that race is more subjected to environmental justice issues than poverty, with indices computed for minority being stronger and more significant. In terms of the parishes that suffer most in terms of environmental injustice are Ascension, East Baton Rouge, and Orleans.

The study has several policy implications. Identification of potential areas with environmental justice issues in advance allow policy makers to make informed decisions on industrial zone planning and siting toxic industrial facilities in line with Federal and EPA policies/guidelines. Knowledge on such environmental justice issues further enable policy makers to plan appropriate welfare measures to alleviate negative social and environmental impacts.

\section{Research Limitations}

Conclusions derived from this study have several limitations. Designing an appropriate methodology to investigate potential environmental injustice concerns is complex. The indices used in this study did not address the actual health risks associated with different TRI emissions. At present, there is no standardized approach to measure environmental justice and the factors that cause environmental justice conditions are often multidimensional. The choice of scale, difficulties in capturing the true boundaries of a community with GIS, setting the buffer distance, and varying health risks of different chemicals can influence the final outcomes of the study.

CERI and TDDI were employed in this study to determine whether the low income and minority populations in the study area are disproportionately exposed to environmental hazards. Despite their wide applications, the accuracy and comparability of environmental justice indices are under scrutiny of some researchers. However, indices are useful tools to explore the relationship between environmental justice and sociological constructs of race, ethnicity, or poverty. They provide benchmarks for further scholarly research based on preliminary evidence, and allow comparisons between different locations to reveal the degree of environmental inequity.

Environmental justice assessment outcomes can also be sensitive to the shape and size of distance buffers. Selecting and setting an appropriate buffer distance is a question often faced by environmental justice researchers. The basis for buffer distance selection should be well justified because the buffer distance ultimately becomes an influential variable that determines whether environmental inequities exist in an area under investigation (Cutter, 1998). The spatial resolution of the enumeration units may affect the final outcome of the analysis.

Selecting the appropriate geographic scale of analysis is another important aspect in environmental justice research (Cutter, 1998). Some of the commonly used units of analysis include county, city, zip code, census tract, and census blocks. Different studies conducted on same geographical region have led to contradictory or varying conclusions due to the use of different scales/enumeration units of analysis (Maantay, 2002). For instance, McMaster et al. (1997) observed strong relationship between 
minority and TRI sites at county level for the Twin Cities - Minneapolis and Saint Paul, while at the scale of the city of Minneapolis, a stronger relationship was observed between low-income populations and TRI sites. Cutter et al. (1998) further identified evidence for environmental inequity at the county level of analysis; however, no conclusive evidences were observed between vulnerable populations and toxic facilities when analysis was performed at the census tract level.

Furthermore, it is uncertain whether the poor and minority communities moved into areas close to TRI facilities after the establishment of TRI facility due to increased economic opportunities, low transportation costs, and low property values. Hence, more sound methodologies are required to compensate for these factors. The study used year 2000 census data for the analysis, and the population characteristics are believed to be greatly affected by Hurricane Katrina occurred in 2005. Despite these limitations, this study can be used as a preliminary assessment of the existence of environmental justice in the Mississippi industrial corridor in Louisiana. The same methodology can be applied to other regions for environmental justice assessment.

\section{REFERENCES}

[1] Atlas: The Louisiana Statewide GIS (2009): http://atlas.lsu.edu , Accessed June 2009.

[2] Bowen, W.M., Salling, M.J., Haynes, K.E., Cyran, E.J. (1995): Toward Environmental Justice: Spatial Equity in Ohio and Cleveland. - Annals of the Association of American Geographers, 85(4): 641-663. (http://www.informaworld.com/smpp/title content=t7883 52614 $\sim \mathrm{db}=$ all $\sim \mathrm{tab}=$ issueslist $\sim$ branches $=85-\mathrm{v} 85)$.

[3] Capek, S. (1993): The environmental justice frame: A conceptual discussion and application. - Social Problems 40: 5-25.

[4] Chakraborty, J., Armstrong, M.P. (1997): Exploring the use of buffer analysis for the identification of impacted areas in environmental equity assessment. - Cartography and Geographic Information Systems 24: 145-158.

[5] Chakraborty, J., Forkenbrock, J., Schweitzer, L. (1999): Using GIS to Assess the Environmental Justice Consequences of Transportation System Changes. - Transactions in GIS 3: 239-258.

[6] Cutter, S.L. (1998): Issues in Environmental Justice Research. - Proceedings of the Geographic Information Systems in Public Health, $3^{\text {rd }}$ National Conference, San Diego, 525-531.

[7] Executive Order 12898 (1994): Federal Actions to Address Environmental Justice in Minority Populations and Loc-income Populations. - February 11, 1994.

[8] Fisher, J.B., Kelly, M., Romm, J. (2002): Scales of environmental justice: Combining GIS and spatial analysis for air toxics in West Oakland, California. - Health and Place 12: 701-714.

[9] General Accounting Office (1983): Siting of Hazardous Waste Landfills and Their Correlation, Racial and Economic Status of Surrounding Communities. - General Accounting Office, Washington, D.C., U.S.A.

[10] Gottlieb, M.S. (1980): Lung cancer and the petroleum industry in Louisiana. - Journal of Occupational Medicine 22(6): 384-388.

[11] Harner, J., Warner, K., Pierce, J., Huber, T. (2002): Urban Environmental Justice Indices. - The Professional Geographer 54(3): 318-331.

[12] Jerrett, M., Burnett, R.T., Kanaroglou, P., Eyles, J., Finkelstein, N., Giovis, C., Brook, J.T. (2001): A GIS - Environmental Justice Analysis of Particulate air Pollution in Hamilton, Canada. - Environment and Planning A 33: 955-973. 
[13] Johnson, R.S.,Kirk, A.R. (2004): GIS mapping of Environmental Justice Census Characteristics. - Final Report SPR 304-291, Oregon Department of Transportation Research Unit and United States Federal Highway Administration, October, 2004.

[14] Kahn, H.A., Sempos, C.T. (1989): Statistical Methods in Epidemiology. - Oxford University Press, New York.

[15] Kumar, C.M. (2002): GIS Methods for Screening Potential Environmental Justice Areas in New England. - MS Thesis, Department of Urban Studies and Planning, Massachusetts Institute of Technology.

[16] Kurtz, H.E. (2003): Scale Frames and Counter-scale Frames: Constructing the Problem of Environmental Injustice. - Political Geography 22: 887-916.

[17] Larson, J., Claussen, J. (2004): Statistical Environmental Justice Assessment for a Transportation Corridor. - Environmental Practice 6: 71-78.

[18] Louisiana Environmental Action Network (2009): Maps and TRI Data, Louisiana Environmental Action Network. - http://leanweb.org/content/view/37 Accessed October, 2009.

[19] Maantay, J. (2002): Mapping Environmental Injustices: Pitfalls and Potential of Geographic Information Systems in Assessing Environmental Health and Equity. Environmental Health Perspectives 110(2): 161-171.

[20] McMaster, R., Leitner, H., Sheppard, E. (1997): GIS-based environmental equity and risk assessment: methodological problems and prospects. - Cartography and Geographic Information Systems 24(3): 172-189.

[21] Mennis, J. (2002): Using Geographic Information Systems to Create and Analyze Statistical Surfaces of Population and Risk foe Environmental Justice Analysis. - Social Science Quarterly 83(1): 281-297.

[22] Mertz, C.K., Slovic, P. (2004): Discrimination, Vulnerability, and Justice in the Face of Risk. - Risk Analysis 24(1): 115-129.

[23] Mohai, P., Saha, R. (2007): Racial Inequality in the Distribution of Hazardous Waste: A National-Level Reassessment. - Social Problems 54(3): 343-370.

[24] Moynihan, M.T. (2007): An Environmental Justice Assessment of the Light Rail Expansion in Denton County, Texas. - MS Thesis, University of North Texas.

[25] Pollock, P.H, Vittas, M.E. (1995): Who bears the Burden of Environmental Pollution? Race, Ethnicity, and Environmental Equity in Florida. - Social Science Quarterly 76(2): 294-309.

[26] Sheppard, E., Leitner, H., McMaster, R.B., Tian, H. (1999): GIS based measures of Environmental Equity: Exploring their Sensitivity and Significance. - Journal of Exposure Analysis and Environmental Epidemiology 9: 18-28.

[27] Subra, W. (2008): Highest Ranking Parishes and Industrial Facilities in Louisiana for Chronic human Health Risk. - Louisiana Environmental Action Network. (http://leanweb.org/news/latest/highest-ranking-parishes-and-industrial-facilities-inlouisiana-for-chronic-human-health-risk.html Accessed October 2009).

[28] Sui, D.Z., Giardino, J. (1995): Applications of GIS in environmental equity analysis: a multi-scale and multi-zoning scheme study for the city of Houston, Texas, USA. Proceedings GISrLIS '95. GISrLIS'95 Annual Conference and Exposition. 14-16 November 1995, Nashville, TN, 950-959.

[29] U.S. Census Bureau (2008): http://www.census.gov/pubinfo/www/hotlinks.html Accessed on October 2009.

[30] United States Environmental Protection Agency (2009): http://www.epa.gov/, Accessed October, 2009. 